\title{
THE CONSEQUENCES OF THE CONTEMPORARY OWNERSHIP TRANSFORMATIONS IN POLISH AGRICULTURE
}

Integration in the domain of agriculture constitutes one of the most difficult problems in the process of accession of Poland to the European Union. Small acreage of farms (7.9 hectares on the average) and the excess employment in agriculture (27\% of the professionally active population), when compared with the share of agriculture in the GDP, amounting to $6.3 \%$, constitute confirmation of the low effectiveness and competitiveness of Polish agriculture. It has been expected that privatization and restructuring of the former state farms might bring an improvement with this respect.

In 1992 the process was started of taking over and redistribution of the land previously belonging to the state farms, which, at the beginning of the ownership transformations occupied 4,276 thousand hectares, while their total debt reached 2 billion Polish zlotys. The share of the state farms in total area of agricultural land was distributed very unevenly over the country and ranged between a couple of percentage points in the voivodships of Central and Eastern Poland and more than $40 \%$ in Norther and Western Poland (Fig. 1).

Until the end of 1997 the Agency for the Agricultural Property of the State Treasury ${ }^{1}$ took over 4,592 thousand hectares of land, out of which 3,752 thousand hectares $(81.7 \%)$ had belonged previously to the state farms, 594 thousand hectares (12.9\%) - to the State Land Fund, and 246 thousand hectares (5.4\%) - to other agents. As many as 1,666 state farms were liquidated, of which more than $70 \%$ were located within Northern and Western Poland. Agricultural land constituted $84.4 \%$ of the land taken over by the Agency.

Out of the land taken over by the Agency until the end of 1997, 697 thousand hectares, i.e. $15.2 \%$, were transferred over to new owners in a permanent manner. This took place mainly through the sale or the free of

\footnotetext{
1 Institution involved in implementation of the ownership transformations in state farming, established on the basis of the law of October 19th, 1991.
} 


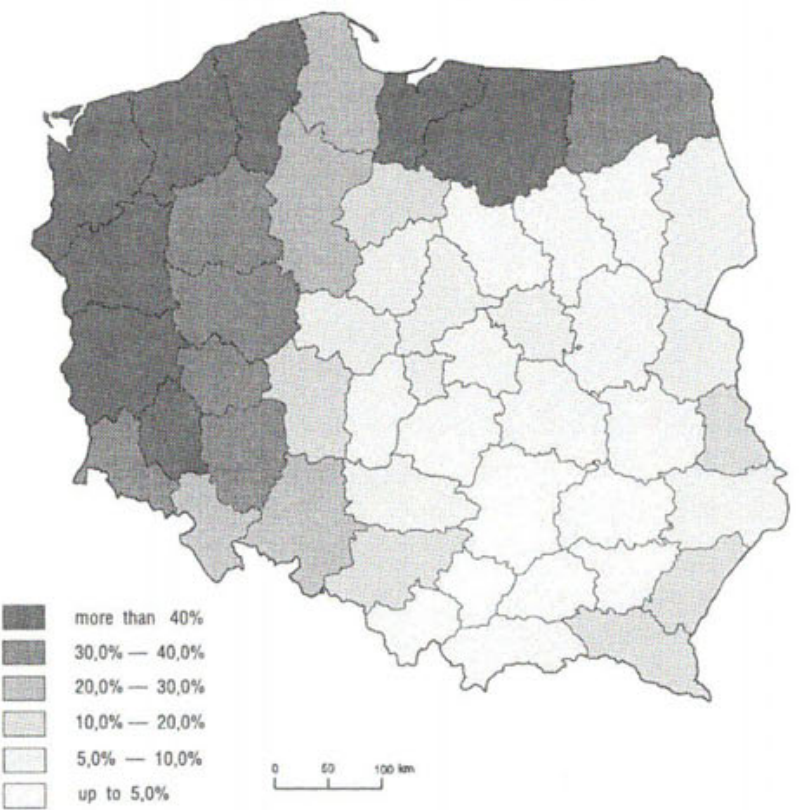

Fig. 1. Shares of the state farms in total area of agricultural land in 1990.

charge donations to, in particular, communes, State Forest units, as well as legal persons of the churches. The state treasury still owns 3,895 thousand hectares, i.e. $84.8 \%$ of the land taken over. This land is managed through lease, administration ${ }^{2}$, as well as use and hereditary tenure by other agents, such as, for instance, National Parks and State Forests.

Table 1

The land use structure of the land taken over by the Agency for the Agricultural Property of the State Treasury

\begin{tabular}{|l|c|c|}
\hline Land categories & $\begin{array}{c}\text { Surface in } \\
\text { thous. hectares }\end{array}$ & $\begin{array}{c}\text { Shares } \\
\text { in \% }\end{array}$ \\
\hline TOTAL & 4,592 & 100.0 \\
Agricultural land & 3,877 & 84.4 \\
$\quad$ including: arable land & 2,989 & 65.1 \\
$\quad$ orchards & 23 & 0.5 \\
$\quad$ permanent grasslands & 865 & 18.8 \\
Forests and forest land & 153 & 3.3 \\
Areas under waters & 331 & 7.3 \\
$\quad$ including: lakes & 262 & 5.7 \\
Other land (transport, settlements, various, wasteland) & 231 & 5.0 \\
\hline
\end{tabular}

Source: data from the Agency of the Agricultural Property of the State Treasury, 1998.

${ }^{2}$ Administration constitutes a form of the managerial contract, reserved for the assets which under current circumstances cannot be rationally disposed of through lease or sale. 
Table 2

Use of land taken over by Agency for the Agricultural Property of the State Treasury

\begin{tabular}{|l|c|r|}
\hline Disposition categories & $\begin{array}{c}\text { Surface in } \\
\text { thous. hectares }\end{array}$ & $\begin{array}{c}\text { Shares } \\
\text { in \% }\end{array}$ \\
\hline Total of land taken over & 4,592 & 100.0 \\
Land given over in a permanent way & 697 & 15.2 \\
$\quad$ including: through sale & 581 & 12.7 \\
$\quad$ free of charge & 107 & 2.3 \\
$\quad$ brought as contribution to commercial code companies & 9 & 0.2 \\
Land still owned by the Agency & 3,895 & 84.8 \\
including: leased out & 2,890 & 62.9 \\
$\quad$ administered & 249 & 5.4 \\
$\quad$ managed and in hereditary tenure & 109 & 2.4 \\
Land still to be disposed of & 647 & 14.1 \\
\hline
\end{tabular}

Source: data of the Agency for the Agricultural Property of the State Treasury, 1998.

An essential role in the course of ownership transformations in Polish agriculture was played by the process of debt regulation of the state farms. The most important form in the debt liquidation process was the banking conciliation procedure. The average remission in the conciliation agreements settled reached $59.6 \%$ of the debt value. The restructuring of the state farm debts contributed to the improvement of their financial position and certainly accelerated the process of their transformation.

The provinces of the Western and Northern Poland feature the largest surfaces and the highest shares of land of the former state farms disposed

Fig. 2. Shares of the stateowned land in total area of agricultural land in 1997.

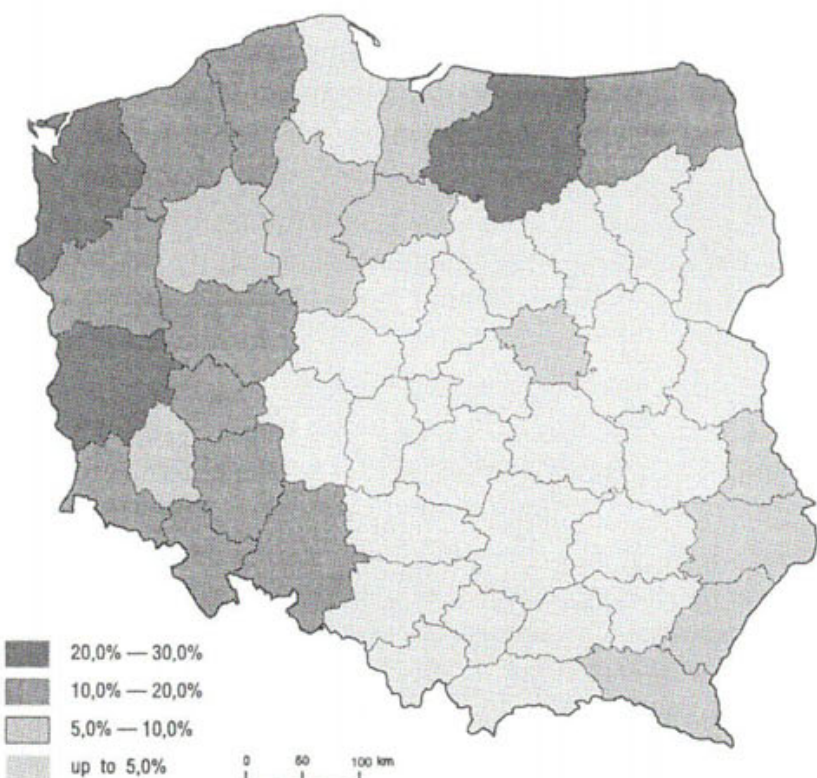


of until now. In some of them the share of the state land in the total area of agricultural land decreased by even more than $30 \%$.

The basic methods of disposing of the land transferred in the process of ownership transformations refer to lease and sale, preceded by the legally obligatory tenders. During six years 3,471 thousand hectares of land were leased out and sold. This led to appearance of some 4.7 thousand private farms with average surface area of 500 hectares, and to the increase of acreage of 170 thousand farms by, on the average, 4 hectares. Thus, a concentration of land within the farms exceeding 10 hectares of surface occurred. In the years 1988-1996 the share of the numbers of the farms exceeding 10 hectares of land increased merely from $17.2 \%$ to $19.1 \%$, while the share of land within such farms increased from $41.2 \%$ to $52.7 \%$ of the total land owned by private farms.

In the same period of 1988-1996 the average surface of the private farm increased merely from 7.05 to 7.91 hectare. Yet, in the regions where the interest in the purchase or leasing of land of the former state farms is the highest, that is - in Northern and Western Poland - the increase of the average surface area of private farms has been much more intensive (see Fig. 3). In some voivodships the average area of the private farms increased namely by more than 5 hectares (like in Elbląg, Koszalin or Szczecin voivodships). These are the regions, though, in which the average magnitude of a farm had always been much bigger than the national average in Poland. The smallest acreages of private farms still persist in Southern

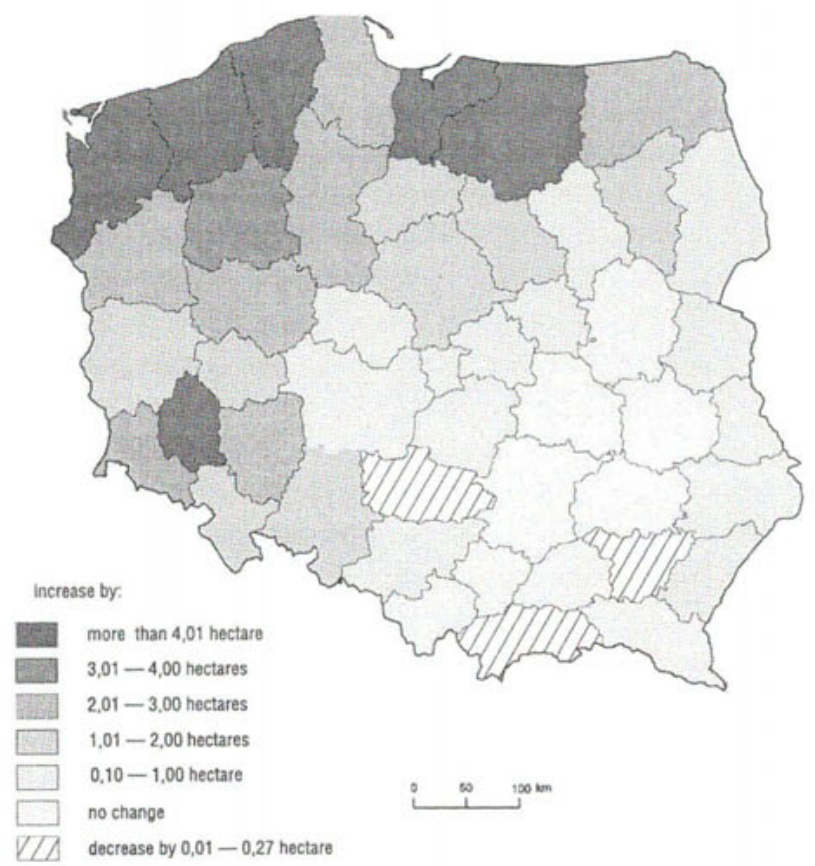

Fig. 3. Changes of the average acreage of private farms in the years 1988-1997. 
Poland, where the average area of a farm often does not exceed 4 hectares (like in Bielsko-Biała, Cracow, Krosno or Rzeszów voivodships).

The process of transformations in the sector of state agriculture constitutes in the long-term perspective the basis for the reconstruction of the functional and spatial structure of rural areas. It brings about, as well, though, the hazards of socio-economic nature. One of them is constituted by the rising unemployment rates. In the years 1990-1996 employment in the state farms decreased by $75 \%$, and in relation to land area - from 10 down to 2-3 persons per 100 hectares of agricultural land. Some 55 thousand of the former employees of the state farms are currently jobless. The problem of unemployment in the regions of domination of the former state farms is not significant on the national scale, insofar as it accounts for $2.5 \%$ of the total unemployment in Poland and for approximately $6 \%$ of rural unemployment. The essence of the problem consists in the concentration of the population having lost their jobs due to the liquidation and restructuring of the state farms in the areas featuring otherwise high structural unemployment rates.

The unemployment problem among the persons previously working in the liquidated state farms is insofar significant as it touches young families, usually rearing many children, and usually with low revenues. The per capita incomes in the families of the employees of the state farms were by some $15-20 \%$ lower than on the average in the employees' families in total and by $25-30 \%$ lower than in the families of private farmers (Dzun, 1993) ${ }^{3}$. Besides this, the employees of the state farms were as a rule specialized in just one type of activity. Not all of them were capable of facing the various duties which are linked with the management of a private farm. Only few of them decided to purchase or lease the land of the liquidated state farms, while most of them counted on getting employed by the new owners (Szot, 1996). An essential barrier in purchasing the land was also constituted by the lack of adequate financial means.

Numerous undertakings took place aiming at securing the jobs for the employees of the liquidated state farms. These undertakings include:

- the special forms of lease contracts, involving obligation of employing for a definite time a definite number of persons,

- support for these initiatives which make it possible to maintain the adequate level of employment in the farms established, such as, for instance: reductions in the payment of instalments in case of estate sale, whenever the purchaser creates new jobs, and the reductions for the tenants, even in the form of freeing them from rent payments for five years, if new jobs are created,

${ }^{3}$ Still, this low level of incomes was to a large extent compensated for by the broad spectrum of social benefits (like, in particular, free accomodation, health care, social care) and numerous allowances. 
- directing the unemployed to the public intervention works or reschooling for the new professions,

- formation of new jobs in the framework of the Jobless Activation Fund, established due to PHARE aid means within the voivodships of Northern and Western Poland, i.e. in the areas of high structural unemployment.

The liquidation of the state farms affected also local communities of many regions. These farms functioned, namely, within the rural areas featuring low level of development of the social and technical infrastructure. That is why the state farms were charged with such duties as establishment of the education, culture and health care outlets, and securing of access to them for the employees of the state farms. These centers were also frequented by the rural population of the given area. Along with liquidation of the state farms numerous centers of the social infrastructure ceased to exist as well. Local authorities were not capable of directing adequate financial means for their upkeep.

The transformations taking place in the recent years in Polish agriculture caused that an increasing importance is attached to the abandonment of the sectoral farming policy to the advantage of the comprehensive rural policy (Wilkin, 1996). This tendency is expressed, in particular, in the popularization of the idea of the multifunctional development of the rural areas, increased accessibility of credits for the development of rural infrastructure, as well as broadening of the scope of the farming consultancy services so as to encompass the issues exceeding agricultural production (e.g. the support for agrotourism).

\section{REFERENCES}

D z u n W., 1993, Problemy restrukturyzacji państwowych gospodarstw rolnych (Problems of restructuring the state farms; in Polish), in: K.Duczkowska-Małysz, ed., Przedsiębiorczość na obszarach wiejskich. W stronę wsi wielofunkcyjnej, Instytut Rozwoju Wsi i Rolnictwa PAN, Warszawa, 137-146.

S z ot E., 1996, Bezrobocie po byłych PGR. Problem coraz mniejszy, ale jednak jest (Unemployment after the former state farms. The problem is decreasing, but is still there; in Polish), Rzeczpospolita, 301 (4555), 28-29 December 1996, 9.

W il k in J., 1996, Strategia rozwoju obszarów wiejskich (Strategy of development of rural areas; in Polish), Gospodarka Narodowa, 11, 66-73. 